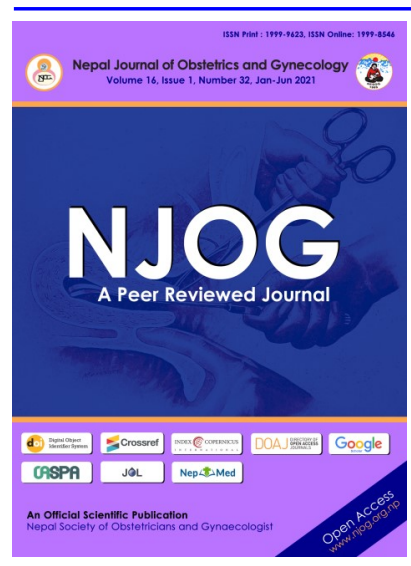

CORRESPONDENCE

Dr Beemba Shakya

Department of OBGYN, Paropakar Maternity and Women's Hospital, Thapathali, Kathmandu, Nepal

Email:

bshakya02@gmail.com; Phone: +977-9840185953

Received: October 7, 2020 Accepted: April 1, 2021

\section{Citation:}

Shakya B. Analysis of Ectopic Pregnancy at Paropakar Maternity and Women' Hospital. Nep J Obstet Gynecol. 2021;16(32):52-56. DOI: https://

doi.org/10.3126/

njog.v16i1.37519

\title{
Analysis of Ectopic Pregnancy at Paropakar Maternity and Women's Hospital
}

Beemba Shakya

Paropakar Maternity and Women's Hospital, Thapathali, Kathmandu

\section{ABSTRACT}

Aims: To analyze the patients with ectopic pregnancy.

Methods: The medical records of 88 ectopic pregnancies at Paropakar Maternity and Women's Hospital were reviewed from January to July 2020. Data pertaining patient characteristics, age, gravida, risk factors, clinical presentation, diagnostic modality, site of ectopic pregnancy, management and morbidity associated with it were retrieved and was analyzed using SPSS version 16.0.

Results: Among 88 ectopic pregnancies, $28 \%$ occurred in $30-34$ years, $65 \%$ were multipara, presented abdominal pain (72\%), vaginal bleeding $(60 \%)$ and amenorrhoea (57\%); $72 \%$ had ampullary ectopic, $60 \%$ had ruptured ectopic, $99 \%$ underwent surgical management and $41 \%$ required blood transfusion. There was no any mortality.

Conclusions: Abdominal pain, vaginal bleeding and amenorrhoea were the common presentation. Only $60 \%$ had ruptured ectopic pregnancy. Almost all had surgical management.

Keywords: ectopic pregnancy, hemodynamic instability, surgical management

\section{INTRODUCTION}

Ectopic pregnancy is the implantation of a fertilized ovum outside the endometrial cavity. It occurs in approximately $0.5-2 \%$ of pregnancies and is potentially life threatening. ${ }^{1,2}$ The possible causes of increase in incidence of ectopic pregnancy are pelvic inflammatory disease, use of intrauterine contraceptive device, tubal surgical procedures, induced abortion followed by infection, increasing age, smoking, etc. ${ }^{3}$ Diagnosis requires a high index of suspicion as the classic triad of amenorrhoea, abdominal pain and vaginal bleeding is not seen in majority of cases. Women may present with nonspecific symptoms, unaware of an ongoing pregnancy or even present with hemodynamic shock. ${ }^{4}$ Other symptoms like nausea, pain lower abdomen, shoulder pain may also be present. ${ }^{3}$

The $95 \%$ of ectopic pregnancies occur in fallopian tube and out of which 55\% occur in ampulla, isthmus (20-25\%), fimbriae $(17 \%)$ and interstitial segment (2-4\%). Other sites of ectopic pregnan cy are ovarian $(0.5-1 \%)$, cervical $(0.1 \%)$ and abdominal pregnancy $(0.03 \%){ }^{5}$ The diagnosis of ectopic pregnancy can be difficult. Measurement of serum progesterone, serial serum beta-human chorionic gonadotrophin ( $\beta$-hCG) levels, transvaginal ultrasonography (TVS) and laparoscopy are the diagnostic tools. ${ }^{6,7}$ Early diagnosis and prompt treatment is associated with better outcome. ${ }^{8}$ Treatment options for ectopic pregnancy include medical therapy (methotrexate) $)^{9}$ and surgery (open or laparoscopic). ${ }^{10,11}$ Management depends on individual basis. ${ }^{12}$ The purpose of this study was to analyze the patients with ectopic pregnancy.

\section{METHODS}

This was a retrospective medical record review at Paropakar Maternity and Women's Hospital (PMWH) in Kathmandu. Ethical approval was taken from the hospi- 
tal Instittutional Review Committee. The medical records of ectopic pregnancy were reviewed from 15 January to 15 July 2020 . Data pertaining patient characteristics, age, gravida, risk factors, clinical presentation, diagnostic modality, site of ectopic pregnancy, management and morbidity associated with it were retrieved and descriptive analysis done using SPSS version 16.0.

\section{RESULTS}

There were 88 ectopic pregnancies out of 10123 deliveries $(0.86 \%)$ in six months and $18(20.5 \%)$ cases were referred-in from different hospitals. Fourteen cases $(15.9 \%)$ did not have history of amenorrhoea. [Table-1]

Table-1: Distribution of patient characteristics $(n=88)$

\begin{tabular}{|c|c|c|}
\hline \multicolumn{2}{|c|}{ Patient characteristics } & $\mathrm{N}(\%)$ \\
\hline \multirow{6}{*}{ 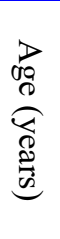 } & $15-19$ & $2(2.3)$ \\
\hline & $20-24$ & $22(25)$ \\
\hline & $25-29$ & $21(23.9)$ \\
\hline & $30-34$ & $25(28.4)$ \\
\hline & $35-39$ & $13(14.8)$ \\
\hline & $40-44$ & $5(5.7)$ \\
\hline \multirow{5}{*}{ 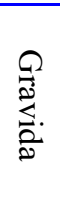 } & G1 & $30(34)$ \\
\hline & G2 & $21(23.9)$ \\
\hline & G3 & $21(23.9)$ \\
\hline & G4 & $11(12.5)$ \\
\hline & G5 & $5(5.7)$ \\
\hline \multirow{11}{*}{ 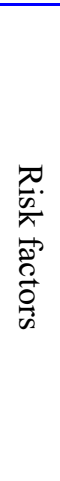 } & Previous abortion $\geq 1$ & $22(25)$ \\
\hline & Previous ectopic pregnancy & $4(4.5)$ \\
\hline & Bilateral tubal ligation & $4(4.5)$ \\
\hline & Previous LSCS & $13(14.8)$ \\
\hline & Use of medical abortion & $7(7.9)$ \\
\hline & Use of Inj DMPA & $4(4.5)$ \\
\hline & $\begin{array}{l}\text { Use of emergency contraceptive } \\
\text { pills }\end{array}$ & $1(1.1)$ \\
\hline & Use of oral contraceptive pills & $2(2.3)$ \\
\hline & Subfertility & $3(3.4)$ \\
\hline & In-vitro fertilization & $1(1.1)$ \\
\hline & History of tuberculosis & $1(1.1)$ \\
\hline \multirow{8}{*}{ 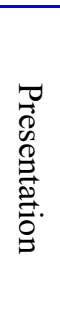 } & Amenorrhoea & $50(56.8)$ \\
\hline & Abdominal pain & $63(71.6)$ \\
\hline & Vaginal bleeding/spotting & $53(60.2)$ \\
\hline & Vomiting & $4(4.5)$ \\
\hline & Triad & $14(15.9)$ \\
\hline & Hypovolemic shock & $2(2.3)$ \\
\hline & Abdominal tenderness & $54(61.4)$ \\
\hline & Cervial motion tenderness & $45(51.1)$ \\
\hline
\end{tabular}

Majority of the cases diagnosed by clinical examination alone $(47.7 \%)$ followed by additional ultrasonography (31.8\%). [Table- 2]

Almost all cases were tubal ectopics. Site of tubal ectopic pregnancy were mentioned in $72(81.8 \%)$ cases. Majority of the cases $(53 ; 60.2 \%)$ were ruptured tubal ectopic. Among 35 (39.8\%) of unrup tured cases 12 were chronic ectopic pregnancy. [Table-3]

Table- 2: Diagnostic modality

\begin{tabular}{lc}
\hline Diagnostic modality & $\mathrm{N}(\%)$ \\
\hline Clinical alone & $42(47.7)$ \\
Clinical + USG & $28(31.8)$ \\
Ultrasonography (USG) & $12(13.6)$ \\
Serial $\beta$-hCG + USG & $6(6.8)$ \\
\hline
\end{tabular}

Table- 3: Site, side and nature of ectopic pregnancy

\begin{tabular}{clc}
\hline \multicolumn{2}{l}{ Variables } & $\mathrm{N}(\%)$ \\
\hline \multirow{4}{*}{ Site } & Ampulla & $63(71.6)$ \\
& Isthmus & $6(6.8)$ \\
& Fimbria & $2(2.3)$ \\
& Cornua & $1(1.1)$ \\
Side & Right & $49(55.7)$ \\
& Left & $39(44.3)$ \\
& Ruptured & $53(60.2)$ \\
Nature & Unruptured & $35(39.8)$ \\
& Unruptured chronic & $12(13.6)$ \\
\hline
\end{tabular}

Majority of the cases were surgically managed (87; $98.9 \%$ ) and the most commonly performed surgical procedure was salpingectomy $(81.8 \%)$. One case underwent left cornual wedge resection with left salpingectomy and right tubal ligation in 43 years, $\mathrm{G}_{5} \mathrm{P}_{3+1}$ with previous LSCS, ultrasonography (USG) revealed ectopic pregnancy. Patient underwent laparotomy and had left ruptured cornual ectopic pregnancy with hemoperitoneum 500 $\mathrm{ml}$. Two units blood transfused and discharged on $3^{\text {rd }}$ POD. One case had medical management with single dose of Methotrexate (MTX) $50 \mathrm{mg}$ intramuscularly. She was 32 years, $\mathrm{G}_{2} \mathrm{P}_{1}$, previous lower segment cesarean section (LSCS) with secondary subfertility and in-vitro-fertilization (IVF) conception who did not have amenorrhoea, presented with pain abdomen and per vaginal $(\mathrm{P} / \mathrm{V})$ bleeding for 15 days. Her serum $\beta$-hCG was $392 \mathrm{mIU} / \mathrm{ml}$ and TVS revealed $(18 \times 17 \mathrm{~mm})$ left adnexa ectopic pregnancy without cardiac activity. [Table- 4]

Table-4: Management of ectopic pregnancy

\begin{tabular}{lc}
\hline Surgical procedure & $\mathrm{N}(\%)$ \\
\hline Salpingectomy & $72(81.8)$ \\
Salpingectomy + contralateral tubectomy & $9(10.2)$ \\
Salpingectomy + cystectomy & $1(1.1)$ \\
Cornual resection + repair & $1(1.1)$ \\
Salpingo-ophorectomy & $4(4.5)$ \\
\hline
\end{tabular}


Regarding morbidity associated with ectopic pregnancy $36(40.9 \%)$ had blood transfusion and 11 $(12.5 \%)$ required general anesthesia (GA). Patients requiring to stay hospital for more than 7 days $(15.9 \%)$ were because previously they were diagnosed as threatened abortion (1/14), complete abortion $(2 / 14)$, adnexal cyst (1/14) and pregnancy of unknown location (PUL) (4/14); after 4 to 6 days, following serial $\beta$-hCG and USG, underwent laparotomy for ectopic pregnancy. One case $(1 / 14)$ was medically managed and another $(1 / 14)$ had bowel serosa injury repair. Four (4/14) had ruptured ectopic pregnancy with blood loss ranging from 1500 to $3000 \mathrm{ml}$ requiring four to six units of blood transfusion. There was no maternal mortality.

\section{DISCUSSION}

The incidence of ectopic pregnancy was $0.86 \%$ which was similar to a study by Yadav A et $\mathrm{al}^{13}$ $(0.89 \%)$ whereas slightly higher incidence was seen in other studies $1.3 \%,{ }^{14} 1.4 \%,{ }^{15} 1.8 \%{ }^{16}$ and $1.9 \%{ }^{17}$

The majority of ectopic pregnancy cases occurred in 30 to 34 years age group (28.4\%) which was similar to a study by Kaveri et al, ${ }^{16}$ (31 to 35 years). However, other studies ${ }^{17-19}$ found more of these cases in 20 to 30 years age group. In this study, more of ectopic pregnancy was seen in multiparous $(65 \%)$ which is similar to various other studies. $13,16,17,19,20$

Amongst the risk factors studied, history of having previous abortion was the most common finding (25\%). Similar observations were seen by Rajita et al $(28 \%),{ }^{8}$ Rajendra et al $(32.6 \%)^{17}$, Shraddha et al $(29 \%),{ }^{21}$ Archana et al $(31.2 \%)^{22}$ and Arati et al $(46.2 \%) .{ }^{23}$ This could be due to infection following abortion causing tubal damage or dysfunction. In this study, use of medical abortion was $7.9 \%$ which is comparable to a study by Shraddha et al $(9.7 \%){ }^{21}$

The self medication of abortificient without supervision increases the chances of missing the ectopic pregnancy. The overall risk of developing ectopic pregnancy by over the counter abortificient is as high up to $1.9 \%$ to $6.5 \%{ }^{24,25}$ In this study, another risk factor, previous ectopic pregnancy was $4.5 \%$ which is similar to studies by Ansa et al $(4.4 \%),{ }^{26}$ Hussam et al $(4.7 \%),{ }^{27}$ Shraddha et al $(3.2 \%)^{21}$, Anita et al $(5.4 \%)^{13}$ and Rajendra et al $(5.7 \%) .{ }^{17}$ This is most likely due to tubal factors that are usually bilateral. In this study, bilateral tubal ligation and previous LSCS were $4.5 \%$ and $14.8 \%$ respectively which is comparable to studies by Mridula et al $(6.4 \%, 12.8 \%){ }^{19}$ Shanti et al $(12.9 \%, 6.4 \%)^{20}$,
Anita et al $(10.9 \%, 26.02 \%)^{13}$ and Bhawana et al $(7.9 \%, 2.6 \%)^{15}$. Similarly, Niteshet $\mathrm{al}^{18}$ had previous LSCS in $11.5 \%$ of their patients. In this study, subfertility was seen in $4.5 \%$ (1.1\% IVF conception) which is similar to studies by Shanti et al $(4.8 \%),{ }^{20}$ Shraddha et al $(3.2 \%)^{21}$ and Anita et al $(2.7 \%)^{13}$, in contrary, it was higher in various other studies Tahmina et al $(18.8 \%),{ }^{4}$ Rajita et al $(18 \%)^{8}$ and Ansa et al $(22.2 \%) .{ }^{26}$ In this study, use of oral contraceptive pills (OCP) and emergency contraceptive pills were $2.3 \%$ and $1.1 \%$ respectively. Use of OCP was seen in studies by Shanti et al $(1.6 \%)^{20}$ and Rajendra et al $(7.6 \%)^{17}$ whereas use of emergency contraceptive pill was higher in a study by Kaveri et al (36.3\%). ${ }^{16}$ Also in this study, $1.1 \%$ had history of tuberculosis which was slightly higher in other studies $3.8 \%{ }^{17}$ and $8.5 \%{ }^{19}$

The presentation of ectopic pregnancy is variable. In this study, the most common presenting symptom was abdominal pain (71.6\%) followed by vaginal bleeding $(60.2 \%)$ and amenorrhoea $(56.8 \%)$ which is similar to the studies by Archana et al $(100 \%, 95 \%, 86.2 \%)^{22}$ and Smita et al $(96 \%, 52 \%$, $48 \%) .{ }^{28}$ However, in this study, amenorrhoea was absent in $15.9 \%$ of the patients. In the absence of amenorrhoea, woman may be unaware of an ongoing pregnancy and hence may not anticipate a pregnancy associated complication. This subjects her to increased risk due to delayed diagnosis. The classic triad of amenorrhoea, pain abdomen and vaginal bleeding was seen in $15.9 \%$ which is in contrast to other studies by Rajendra et al $(53.8 \%),{ }^{17}$ Archana et al $(71 \%)^{22}$ and Smita et al $(60 \%) .{ }^{28}$ Two cases $(2.3 \%)$ presented to hospital in hypovolemic shock while more cases of shock were seen in various other studes by Tahmina et al $(26.4 \%)^{4}$, Smita et al $(32 \%),{ }^{28}$ Archana et al $(42.5 \%)^{22}$ and Rajendra et al $(51.9 \%)^{17}$. In this study, clinical signs of abdominal tenderness and cervical motion tenderness were seen in $61.4 \%$ and $51.1 \%$ respectively which is comparable to a study by Tahmina et al $(75 \%, 58.3 \%) .{ }^{4}$ Hence, in this study, $47.7 \%$ cases could be diagnosed by clinical alone. Diagnosis of ectopic pregnancy can be challenging because presentation can vary significantly. Although clinical examination may raise the suspicion of an ectopic pregnancy, relying on clinical signs and symptoms alone would have missed the diagnosis in $13.6 \%$ of the cases in this study. USG was useful in diagnosing most of these cases along with clinical and serial serum $\beta$-hCG. 
In this study, ectopic pregnancy occurred in fallopian tubes, ampulla (71.6\%) being the most common site followed by isthmus (6.8\%), fimbria (2.3\%) and cornua $(1.1 \%)$ which is similar to other studies. ${ }^{6,18,22,26}$ Similarly, ampullary part of the tube was commonly involved in most of the ectopic pregnancies in various other studies. . $^{13-17,19-21,23,28,29}$ The right side was more frequent than the left which was consistent with different other studies. ${ }^{16,18,21,23,26,29}$ Our hospital being a tertiary level referral centre, $60.2 \%$ of the women had ruptured ectopic pregnancies which is comparable to most of the studies ranging from $56 \%$ to $91.5 \%{ }^{4,13,17,19,21,26}$

Since most of the patients had ruptured ectopic pregnancy, they required emergency laparotomy and salpingectomy $(81.8 \%)$ as life saving measures. Moreover, $13.6 \%$ had chronic ectopic with adnexal adhesion necessitating salpingectomy. Most other studies also underwent salpingectomy as the primary surgery and ranged from $58 \%$ to $96.8 \%$. ${ }^{13-15,17-}$ ${ }^{23,27}$ In this study, $10.2 \%$ underwent salpingectomy with contralateral tubectomy which correlated with a study by Shanti et al (12.9\%), while other studies had as low as $2.1 \%{ }^{23}$ and $2.6 \%{ }^{7}$ to as high as $35 \%{ }^{22}$ Four cases $(4.5 \%)$ had to undergo salpingoophorectomy [chronic ectopic pregnancy with dense adhesion(3) and associated ovarian dermoid cyst(1)] which was comparable to other studies showing $2.1 \%,{ }^{23} 2.5 \%{ }^{27}$ and $3.8 \% .{ }^{17}$ In this study, one patient $(1.1 \%)$ underwent conual resection and repair as was also observed in Rajendra et $\mathrm{al}^{17}$ study whereas slightly higher in Mridula et al study (8.5\%). ${ }^{19}$ Another case $(1.1 \%)$ who had conceived by IVF had met the criteria for medical management; her serum $\beta$-hCG was $392 \mathrm{mIU} / \mathrm{ml}$ and TVS revealed (18X17) $\mathrm{mm}$ left adnexa ectopic pregnancy without cardiac activity and hence received single dose of MTX 50 $\mathrm{mg}$ intramuscularly. Various other studies also reported the medical management with MTX; Rajendra et al $(1.9 \%),{ }^{17}$ Hussam et al $(14.3 \%)^{27}$ and Bhawana et al $(15.8 \%){ }^{15}$

In this study, hemodynamic instability was the major factor of morbidity necessitating blood transfusion in $40.9 \%$ which is similar to a study by Hussam et al $(41.9 \%){ }^{27}$ Various other studies reported the blood transfusion ranging from $54.8 \%$ to $84.6 \%$. $13,15,17,21,23$ General anesthesia was required in $12.5 \%$ in this study whereas other studies reported as high as $30.1 \%{ }^{23}$ and $51.9 \%{ }^{17}$ In this study, $15.9 \%$ had hospital stay of $>7$ days for PUL, hemodynamic instability requiring blood transfusion, medical management and bowel serosa injury repair. In a study by Tahmina et al, ${ }^{4}$ mean duration of hospital stay was $6.6 \pm 2.9$ days. Other studies reported $>10$ days $(21.1 \%),{ }^{17} \geq 8$ days $(12.5 \%)^{6}$ and $>8$ days $(5.6 \%) .^{30}$

Aratiet $\mathrm{al}^{23}$ reported $3.2 \%$ maternal mortality in their study. Fortunately, there was no maternal mortality due to ectopic pregnancy in this study as in majority of other studies. ${ }^{4,6,13,17-19,21,22}$ This may be as a result of prompt and proper management of patients after reporting to the hospital pertaining to improved diagnostic and treatment modalities.

\section{CONCLUSIONS}

Majority of the patients had ruptured tubal ectopic pregnancy. Most of them required surgical management, salpingectomy being the most common. The most common morbidity associated was hemodynamic instability requiring blood transfusion. There was no maternal mortality.

\section{REFERENCES}

1. Mahboob U, Mazhar SB. Management of ectopic pregnancy: a two-year study. J Ayub Med Coll Abbottabad. 2006;18(4):34-7.

2. Laxmi RC, Pradhan B, Duwa S. Annual Analysis of Ectopic Pregnancy in Tertiary Care Hospital. PMJN. 2011;11(1):5-8.

3. Kumar A, Chavali KH, Singh A, Kumar A, Dasari H. Death due to ruptured ectopic pregnancy natural death or negligence. J Indian Acad Forensic Med. 2010;32(3):264-6.

4. Tahmina S, Daniel M, Solomon P. Clinical analysis of ectopic pregnancies in a tertiary care centre in Southern India: A six-year retrospective study. J Clin Diagnost Res. 2016;10(10):136.

5. Bouyer J, Coste J, Fernandez H, Pouly JL, JobSpira N. Sites of ectopic pregnancy: a 10 year population based study of 1800 cases. Hum Reprod. 2002;17(12):3224-30.

6. Mohan S, Thomas M. Ectopic pregnancy: reappraisal of risk factors and management strategies. Int J Reprod Contracept Obstet Gynecol. 2015;4(3):709-15.

7. Caraon SA. Buster JE. Ectopic pregnancy. N Engl J Med. 1993;329(16):1174-81.

8. Jani RS, Munshi DS, Jani SK, Munshi SP. Study of 50 cases of modern management of 
ectopic pregnancy. Int J Reprod Contracept Obstet Gynecol. 2014;3(2):374-9.

9. Lipscomb GH, Stovall TG, Ling FW. Nonsurgical treatment of ectopic pregnancy. N Engl $\mathrm{J}$ Med. 2000;343(18):1325-9.

10. Tulandi T, Saleh A. Surgical management of ectopic pregnancy. Clin Obstet Gynecol. 1999;42(1):31-8.

11. Benson CB, Doubilet PM. Strategies for conservative treatment of cervical ectopic pregnancy. Ultrasound Obstet Gynecol. 1996;8(6):3712.

12. Rakhi, Mital PL, Nupur H, Agarwal A, Makkar P, Fatima A. Ectopic pregnancy: a devastating catastrophe. Sch J App Med Sci. 2014;2 (3A):903-7.

13. Yadav A, Prakash A, Sharma C, Bhabani P, Saha MK. Trends of ectopic pregnancies in Andaman and Nicobar islands. Int J Reprod Contracept Obstet Gynecol. 2017;6(1):1-5.

14. Mooij R, Mgalega GC, Mwampagatwa IH, Dillen JV, Stekelenburg J. A cohort of women with ectopic pregnancy: challenges, diagnosis and management in a low income country. BMC Preg Childbirth. 2018;18:1-7.

15. Priyadarshini B, Padmasri R, Jnaneshwari TL, Sowmya KP, Bhatara U, Hema V. Ectopic pregnancy: a cause for maternal morbidity. Int J Reprod Contracept Obstet Gynecol. 2016;5(3):7004.

16. Patel KS, Nag RS, Jain L. Ruptured ectopic pregnancy, the challenges for the obstetrician: single center prospective study. Intl J of Contemp Med Res. 2018;5(5):1-5.

17. Wakanakar R, Kedar K. Ectopic pregnancy - A rising trend. Intl J Sci Stud. 2015;3(5):18-22.

18. Meena N, Bairwa R, Sharma S. Study of ectopic pregnancy in a tertiary care centre. Int J Reprod Contracept Obstet Gynecol. 2020;9(1):212-5.

19. Shrivastava M, Parashar H, Modi JN. A clinical study of ectopic pregnancy in a tertiary care centre in Central India. Int $\mathbf{J}$ Reprod Contracept Obstet Gynecol. 2017;6(6):2485-90.

20. Asuri SS, Kalpana P. A clinical study of ectopic pregnancy. Int J Reprod Contracept Obstet Gynecol. 2016; 5(11):3750-3.
21. Shetty S, Shetty A. A clinical study of ectopic pregnancies in a tertiary care hospital of Mangalore, India. Innovat $\mathrm{J}$ Med Health Sci. 2014:4:305-9.

22. Mehta A, Jamal S, Goel N, Ahuja M. Aretrospctive study of ectopic pregnancy at a tertiary care centre. Int J Reprod Contracept Obstet Gynecol. 2017;6(12):5241-6.

23. Behera A, Ghadei R, Bal RN. A clinical study of ectopic pregnancy in a tertiary care hospital. Int J Reprod Contracept Obstet Gynecol. 2018;7(11):4461-4.

24. Sarojini, Ashakiran TR, Bhanu BT, Radhika. Over-the-counter MTP Pills and Its Impact on Women's Health. J Obstet Gynaecol India. 2017; 67(1): 37-41.

25.Munshi KS, Thaker RV, Shah JM, Mewada BN. Self-medication of abortion pills and its complications: an observational study. Int J Reprod Contracept Obstet Gynecol. 2018;7:205 $-9$.

26. Islam A, Fawad A, Shah AA, Jadoon H, Sarwar I, Abbasi AN. Analysis of two years cases of ectopic pregnancy. J Ayub Med Coll Abbottabad. 2017;29(1):65-7.

27.Zain H, Albarakati RG, Abdallah YMY, Dhayfallah AT, Elgak S, Mohamed YE, et al. Clinical analysis of ectopic pregnancies in Majmaah, Saudi Arabia. Biomed Res. 2019;30(5):800-4.

28. Singh S, Mahendra G, Vijaylakshmi S, Pukale RS. Clinical study of ectopic pregnancy in a rural setup. A two year survey. Nation Med Res. 2014;4(1):37-9.

29.Patel M, Chavda D, Prajapati S. A retrospective study of 100 cases of ectopic pregnancy: clinical presentation, site of ectopic and diagnosis evaluation. Int J Reprod Contracept Obstet Gynecol. 2016;5(12):4313-6.

30.Udigwe GO, Umeononihu OS, Mbachu II. Ectopic pregnancy: a 5 year review of cases at nnamdiazikiwe university teaching hospital (NAUTH) Nnewi. Niger Med J. 2010;51 (4):160. 